Original research article

\title{
Action of carvacrol in Salmonella Typhimurium biofilm: A proteomic study
}

\author{
Daliah Alves Coelho Trevisan ${ }^{1 *}$, Paula Aline Zanetti Campanerut-Sá ${ }^{1}$, Alex Fiori da Silva ${ }^{2}$, \\ Andreia Farias Pereira Batista ${ }^{1}$, Flavio Augusto Vicente Seixas ${ }^{3}$, Rosane Marina Peralta ${ }^{4}$, \\ Anacharis Babeto de Sá-Nakanishi ${ }^{4}$, Benício Alves de Abreu Filho ${ }^{5}$, Miguel Machinski Junior ${ }^{5}$, \\ Jane Martha Graton Mikcha ${ }^{1}$ \\ ${ }^{1}$ State University of Maringá, Department of Clinical Analysis and Biomedicine, Maringá, Brazil \\ 2 State University of Minas Gerais, Department of Biological Sciences, Ituiutaba, Brasil \\ ${ }^{3}$ State University of Maringá, Department of Technology, Umuarama, Brazil \\ ${ }^{4}$ State University of Maringá, Department of Biochemistry, Maringá, Brazil \\ ${ }^{5}$ State University of Maringá, Department of Basic Health Sciences, Maringá, Brazil
}

\begin{abstract}
Carvacrol presents action in Salmonella Typhimurium biofilms, however the antibiofilm mechanism of this compound has not been fully established yet. In the present study, the aim was to evaluate protein profile changes in $S$. Typhimurium biofilm treated with carvacrol. Proteomic analysis of treated versus untreated biofilm showed several changes in proteins involved with $S$. Typhimurium biofilm and antioxidant activity. The proteins DsbA (thiol: disulfide interchange protein DsbA), LuxS (S-ribosylhomocysteine lyase), DksA (RNA polymerase binding transcription factor DksA), and SODs (superoxide dismutases) A, B and C had their synthesis decreased after treatment with carvacrol. These proteins play a key role in $S$. Typhimurium biofilm formation, demonstrating the dynamic antibiofilm action of carvacrol. The differentially expressed proteins identified provide possible action targets for future studies in order to gain more insight into the mechanism of action of carvacrol on $S$. Typhimurium biofilm.
\end{abstract}

Keywords: Carvacrol; Biofilms; Proteome; Salmonella Typhimurium

\section{Highlights:}

- The data showed the dynamic action of carvacrol in $S$. Typhimurium biofilm.

- Were identified proteins involved in the oxidative stress and quorum sensing.

- Treatment with carvacrol showed a decrease of proteins related to biofilm.

\section{Introduction}

Infections caused by Salmonella spp. remain some of the most frequent foodborne diseases and are among the main global public health concerns (WHO, 2018). It is estimated that this bacterium causes 1.2 million cases of foodborne disease each year in the United States, leading to 23,000 cases of hospitalization and 450 deaths (CDC, 2019). According to the Center for Disease Control and Prevention, different Salmonella serotypes have been associated with foodborne disease outbreaks involving a wide variety of foods such as vegetables and also products of animal origin (CDC, 2018).

The ability of Salmonella spp. to form biofilms on different surfaces contributes to its resistance and persistence in dif- ferent environments (Steenackers et al., 2012). Several studies have demonstrated that Salmonella spp. form biofilms on surfaces that are commonly found in food processing environments (Wang et al., 2016). Bacterial biofilms are recognized as a source of food and surface contamination and can lead to economic losses (Cappitelli et al., 2014). Biofilms are complex communities with a distinct architecture and are more resistant and more difficult to remove than planktonic bacteria (Borges et al., 2016). The resistance of biofilm cells is multifactorial and is related to the barrier promoted by the extracellular polymeric substances, the slow growth rate of sessile cells, the physiological heterogeneity, and the expression of resistance genes (Borges et al., 2016; Cappitelli et al., 2014).

Different strategies have been proposed to control biofilms based on their biological and physical characteristics. Various

\footnotetext{
* Corresponding author: Daliah Alves Coelho Trevisan, State University of Maringa, Department of Clinical Analysis and Biomedicine, Laboratory of Food Microbiology, Brazil; e-mail: daliah.act@hotmail.com http://doi.org/10.32725/jab.2020.014

Submitted: 2020-04-09 • Accepted: 2020-09-08 • Prepublished online: 2020-09-22

J Appl Biomed 18/4: 106-114 • EISSN 1214-0287 • ISSN 1214-021X

(c) 2020 The Authors. Published by University of South Bohemia in České Budějovice, Faculty of Health and Social Sciences.

This is an open access article under the CC BY-NC-ND license.
} 
targets have been suggested to prevent biofilm establishment or induce its disruption, and include inhibition of bacterial adhesion, interference with bacterial communication, induction of dispersal, and eradication of sessile cells (Borges et al., 2016). Currently, natural compounds are studied as an alternative for biofilm control in food processing environments (Bridier et al., 2015). Their broad spectrum of biological activity, as well as the natural origin and low toxicity level makes them an attractive alternative to synthetic compounds (Walsh et al., 2019). Carvacrol is the major component of oregano (Origanum vulgari) essential oil (Burt, 2004), is classified as a Generally Recognized as Safe (GRAS) by Food and Drug Administration (FDA, 2019), and has been applied to control Salmonella spp. biofilm (Amaral et al., 2015; Burt et al., 2014; Trevisan et al., 2018; Uchida et al., 2014). Although the antibiofilm mechanism of carvacrol has not yet been fully established, Knowles et al. (2005) have demonstrated that this compound inhibits matrix formation during the early stages of biofilm development. Other studies showed that anti-biofilm activity of carvacrol appears to be related to disruption of quorum sensing (Burt et al., 2014; Knowles et al., 2005; Tapia-Rodriguez et al., 2017).

Proteomic analysis has been applied to better understand the complexity of biofilm of different bacteria (Giaouris et al., 2013; Mangalappalli-Illathu et al., 2008; Silva et al., 2018) and to evaluate its adaptation to different conditions (Mangalappalli-Illathu et al., 2008; Silva et al., 2018), profiles of resistance and susceptibility to drugs (Magalhães et al., 2017), and tolerance to bioactive agents (Condell et al., 2012). The proteomic approach provides the opportunity to determine the functional genome, but also it facilitates the identification of proteins that may not have been predicted by analysis of the genome (Sharma et al., 2010; Tomlinson and Holt, 2001). Considering antibiofilm properties of carvacrol, this study evaluated the changes in protein profile of Salmonella Typhimurium biofilm treated with this compound.

\section{Materials and methods}

\section{Chemical free radical quenching activity}

The in vitro chemical antioxidant capacities of carvacrol (purity $\geq 98 \%$ Sigma-Aldrich) were evaluated using both the 2,2'-azino-bis-3-ethylbenzothiazoline-6-sulphonic acid (ABTS) and the 1,1-diphenyl-2-picryl-hydrazyl (DPPH) assays (Erel, 2004; Soares et al., 2009). The cationic ABTS form was generated by incubating $3.7 \mathrm{mM}$ ABTS with $1.3 \mathrm{mM}$ potassium persulfate in the dark for $12 \mathrm{~h}$. The assay system comprised the methanolic cationic ABTS $(61 \mu \mathrm{M})$ containing carvacrol at concentrations ranging from 0.0015 to $150.2 \mu \mathrm{g} / \mathrm{ml}$. After one hour, the absorbance decrease was measured at $734 \mathrm{~nm}$. The DPPH assay system comprised ethanolic $10.5 \mathrm{mM}$ DPPH to which samples containing carvacrol ranging from 0.0015 to $751.1 \mu \mathrm{g} / \mathrm{ml}$ were added. After one hour in the dark, the absorbance at $515 \mathrm{~nm}$ was measured. Computation of the $\mathrm{IC}_{50}$ (half-maximal stimulatory concentrations) values was done by numerical interpolation using Stineman's formula (Wagon, 1999). The software used was the Scientist program from MicroMath Scientific Software (Salt Lake City, UT, USA).

\section{Bacterial strain and culture conditions}

Salmonella enterica serovar Typhimurium ATCC 14028 was used in this study. The strain was stored at $-20{ }^{\circ} \mathrm{C}$ in Tryptic Soy Broth (TSB, Difco, Le Pont de Claix, France) containing $20 \%$ glycerol. Prior to use an aliquot of the frozen strain was transferred to Brain Heart Infusion Broth (BHI, Difco, Le Pont de Claix, France) and incubated at $35^{\circ} \mathrm{C}$ for $24 \mathrm{~h}$. The culture was plated on Hektoen Agar (Difco, Le Pont de Claix, France) and incubated under the same conditions.

\section{Biofilm formation and exposure to carvacrol}

Biofilm formation on polypropylene was performed according to Amaral et al. (2015). Briefly, a $S$. Typhimurium culture in TSB $\left(10^{7} \mathrm{CFU} / \mathrm{ml}\right)$ was added to polypropylene coupons $(90 \mathrm{~mm} \times 15 \mathrm{~mm} \times 1 \mathrm{~mm})$ that were incubated for $48 \mathrm{~h}$ at $35^{\circ} \mathrm{C}$. The coupons were washed with saline solution at $0.85 \%(\mathrm{w} / \mathrm{v})$, incubated with TSB supplemented with carvacrol $(624 \mu \mathrm{g} / \mathrm{ml})$ for one hour at room temperature. Biofilms were removed mechanically using cell scraper with $20 \mathrm{ml}$ of $0.85 \%$ saline solution, an aliquot of $1 \mathrm{ml}$ of cell suspension was removed, and the biofilm cultivability was evaluated by the colony forming units (CFU) count. Colony counts were performed in triplicate and the results were expressed as $\log _{10} \mathrm{CFU} / \mathrm{cm}^{2}$. The remaining bacterial suspension $(19 \mathrm{ml})$ was centrifuged at $4500 \times \mathrm{g}$ for $5 \mathrm{~min}$, washed with sterile saline solution at $0.85 \%(\mathrm{w} / \mathrm{v})$ and the obtained pellet was used for the extraction of proteins. Experiments were repeated twice.

\section{Protein extraction}

The pellet obtained from two assays, as described above, was suspended in lysis buffer with protease inhibitor and subjected to sonication (Silva et al., 2018). The sample was centrifuged at $14000 \times \mathrm{g}$ for ten minutes at $4{ }^{\circ} \mathrm{C}$ and the supernatant was used for analysis. Protein concentration was estimated by Bradford method (Bradford, 1976) using bovine serum albumin standard. The 2D Clean-Up Kit (Amersham Biosciences, Piscataway, New Jersey) was used to purify the protein solution according to the manufacturer's instructions.

\section{Two-dimensional (2-D) gel electrophoresis}

The electrophoresis was performed according to Giaouris et al. (2013) with some modifications. Samples containing $400 \mu \mathrm{g} / \mathrm{ml}$ of proteins were suspended with rehydration solution with $0.6 \%$ IPG buffer and applied to the strips (performed in Immobiline DryStrip gels of 13-cm length and $\mathrm{pH}$ gradient 4-7 - GE Healthcare Life Science, Uppsala, Sweden). Rehydration and isoelectric focusing of the strips was performed using the Ettan IPGphor II Isoelectric Focusing system according to the following parameters: 50 volts $(V)$ for rehydration overnight, $500 \mathrm{~V}$ for $1 \mathrm{~h}, 1000 \mathrm{~V}$ for $1 \mathrm{~h}$ and $8000 \mathrm{~V}$ for $3.5 \mathrm{~h}$. Then, the strips were incubated for 30 minutes with equilibration solution containing 1\% DTT and then another $30 \mathrm{~min}$ with equilibration solution containing $2.5 \%$ iodoacetamide. Separation in the second dimension was performed in $12.5 \%$ SDS-polyacrylamide gels in a vertical electrophoretic unit 600 Ruby (GE Healthcare, USA) in two steps: (a) $16.4 \mathrm{~mA}$ per gel during the stacking period and (b) $40 \mathrm{~mA}$ in the separation period. The proteins were fixed ( $1.3 \%$ orthophosphoric acid in $20 \%$ methanol solution) and the gels were stained overnight with Coomassie Blue G250 (Neuhoff et al., 1988). Two-dimensional (2-D) gel electrophoresis was repeated twice.

\section{Image analysis}

Image analysis of 2-D gels was performed using an Image Scanner II system. The spot detection, quantification, and analysis were realized by Image Master Software. Duplicates obtained from 2-D protein patterns in the treatment were separately compared with untreated biofilm. The differentiation in spot intensity was carried out by Image Master Software using a cutoff value $\geq 2$. 0 -fold changes. 


\section{Mass spectrometry analysis}

Spots of interest were subjected to tryptic in-gel digestion (Shevchenko et al., 1996). An aliquot of $4.5 \mu$ (for protein analysis) of peptides resulting from proteins digestion were separated using a C18 (100-6100 mm) RP-nanoUPLC (nanoAcquity, Waters) coupled with a Q-Tof Premier mass spectrometer (Waters) with nanoelectrospraysource at a flow rate of $0.6 \mathrm{ml} / \mathrm{min}$. The gradient was $2-90 \%$ acetonitrile in $0.1 \%$ formic acid over $45 \mathrm{~min}$. The nanoelectrospray voltage was set to $3.5 \mathrm{kV}$, with a cone voltage of $30 \mathrm{~V}$ and source temperature of $100{ }^{\circ} \mathrm{C}$ being used. The instrument was operated in the 'top three' mode, in which one MS spectrum is acquired followed by MS/MS of the top three most-intense peaks detected. After MS/MS fragmentation, the ion was placed on the exclusion list for $60 \mathrm{~s}$ and for the analysis of endogenous cleavage peptides, a real-time exclusion was used (Aragão et al., 2012).

\section{Data analysis}

Spectra were acquired using MassLynx v.4.1 software and raw data files were converted to a peak list format (mgf) without summing the scans using Mascot Distiller software v.2.3.2.0, 2009 (Matrix Science Ldt.). Peptide mass fingerprint data were searched using Mascot engine v.2.3.01 (Matrix Science Ltd.), Salmonella spp. Uniprot 2016 protein database, with carbamidomethylation as fixed modifications, oxidation of methionine as variable modification, one trypsin missed cleavage and a tolerance of 0.1 Da for both precursor and fragment ions.

\section{Search Tool for Retrieval of Interacting Genes/Proteins analysis (STRING)}

The protein interaction network of differentially regulated proteins was obtained using the dataset from the STRING database (Jensen et al., 2009). The obtained protein-protein interaction network was visualized using Cytoscape v 3.6.0 software (Cline et al., 2007).

\section{Results}

\section{Antioxidant activity}

The antioxidant activity of carvacrol was assessed by two different methodologies, DPPH radical scavenging and $\mathrm{ABTS}^{+}$ assay. The $\mathrm{IC}_{50}$ value of carvacrol on $\mathrm{DPPH}$ and $\mathrm{ABTS}^{+}$was $228.12 \pm 2.3$ and $36.34 \pm 3.15 \mu \mathrm{g} / \mathrm{ml}$, respectively, indicating antioxidant activity of the compound.

\section{Proteins changes in S. Typhimurium biofilm exposed to carvacrol}

Carvacrol $(624 \mu \mathrm{g} / \mathrm{ml})$ was able to reduce bacterial counts from $8.1 \log _{10} \mathrm{CFU} / \mathrm{cm}^{2}$ to $4.1 \log _{10} \mathrm{CFU} / \mathrm{cm}^{2}$ on $S$. Typhimurium biofilms. In a previous study, Trevisan et al. (2018) also observed that carvacrol at $624 \mu \mathrm{g} / \mathrm{ml}$ was able to reduce about $50 \%$ of $S$. Typhimurium biofilm in polypropylene. Based on these results, this concentration was used to evaluate the protein changes in the present study.

The protein profile of $S$. Typhimurium biofilms treated and untreated biofilms were compared and differences confirmed in all comparisons were accepted. Using mass spectrometry, 48 protein spots were successfully identified. Among the differentially expressed protein spots in response to carvacrol treatment, 6 were up-regulated, 7 spots were down-regulated, 3 were expressed only after treatment, and 32 were observed only in the control gel (Table 1). The proteins were classified into the following categories based on their functions: carbon metabolism, protein metabolism, nitrogen metabolism, transmembrane transport, metabolism of nucleotides, oxidative stress, amino acid metabolism and quorum sensing.

Table 1. List of identified proteins in biofilm of $S$. Typhimurium ATCC 14028 treated with $624 \mu \mathrm{g} \mathrm{ml}^{-1}$ of carvacrol compared to untreated biofilm

\begin{tabular}{|c|c|c|c|c|c|c|}
\hline Protein & Protein name & $\begin{array}{l}\text { Protein function } \\
\text { (www.uniprot.org) }\end{array}$ & $\begin{array}{l}\text { Fold } \\
\text { change }\end{array}$ & $\begin{array}{l}\text { Nominal } \\
\text { mass/pI }\end{array}$ & $\begin{array}{c}\text { Sequence } \\
\text { coverage } \%\end{array}$ & $\begin{array}{c}\text { Mascot } \\
\text { score }\end{array}$ \\
\hline & UP-REGULATED & & & & & \\
\hline & Protein metabolism & & & & & \\
\hline Tsf & Elongation factor Ts & $\begin{array}{l}\text { Associates with the EF-Tu.GDP complex and induces the } \\
\text { exchange of GDP to GTP }\end{array}$ & Present & $30453 / 5.13$ & 47 & 1422 \\
\hline \multirow[t]{2}{*}{ SerS } & Serine-tRNA ligase & Catalyzes the attachment of serine to tRNA(Ser) & Present & $48835 / 5.39$ & 7 & 191 \\
\hline & Carbon metabolism & & & & & \\
\hline Mdh & Malate dehydrogenase & $\begin{array}{l}\text { Catalyzes the reversible oxidation of malate to } \\
\text { oxaloacetate }\end{array}$ & 2.43 & $32626 / 6.01$ & 3 & 48 \\
\hline TalB & Transaldolase B & $\begin{array}{l}\text { Important for the balance of metabolites in the pentose- } \\
\text { phosphate pathway }\end{array}$ & 14.66 & $35320 / 5.09$ & 12 & 180 \\
\hline \multirow[t]{2}{*}{ SucC } & $\begin{array}{l}\text { Succinyl-CoA ligase [ADP- } \\
\text { forming] subunit beta }\end{array}$ & $\begin{array}{l}\text { This protein is involved in step } 1 \text { of the subpathway that } \\
\text { synthesizes succinate from succinyl-CoA (ligase route) }\end{array}$ & Present & $41740 / 5.29$ & 25 & 396 \\
\hline & Transmembrane transport & & & & & \\
\hline OmpD & $\begin{array}{l}\text { Outer membrane porin } \\
\text { protein OmpD }\end{array}$ & $\begin{array}{l}\text { Forms pores that allow passive diffusion of small } \\
\text { molecules across the outer membrane (By similarity) }\end{array}$ & 2.55 & $39655 / 4.66$ & 57 & 4222 \\
\hline \multirow[t]{2}{*}{ OmpA } & Outer membran protein $\mathrm{A}$ & $\begin{array}{l}\text { Required for the action of colicins } \mathrm{K} \text { and } \mathrm{L} \text { and for the } \\
\text { stabilization of mating aggregates in conjugation }\end{array}$ & 2.81 & $37568 / 5.60$ & 44 & 2286 \\
\hline & Oxidative stress & & & & & \\
\hline AhpC & $\begin{array}{l}\text { Alkyl hydroperoxide } \\
\text { redutase } c\end{array}$ & $\begin{array}{l}\text { Directly reduces alkyl hydroperoxides with the use of } \\
\text { electrons donated by the } 57 \mathrm{kDa} \text { flavoprotein alkyl } \\
\text { hydroperoxide reductase }\end{array}$ & 11.93 & $20848 / 5.03$ & 22 & 85 \\
\hline
\end{tabular}


Table 1. (Continued)

\begin{tabular}{|c|c|c|c|c|c|c|}
\hline Protein & Protein name & $\begin{array}{l}\text { Protein function } \\
\text { (www.uniprot.org) }\end{array}$ & $\begin{array}{l}\text { Fold } \\
\text { change }\end{array}$ & $\begin{array}{l}\text { Nominal } \\
\text { mass/pI }\end{array}$ & $\begin{array}{c}\text { Sequence } \\
\text { coverage } \%\end{array}$ & $\begin{array}{c}\text { Mascot } \\
\text { score }\end{array}$ \\
\hline & Nitrogen metabolism & & & & & \\
\hline \multirow[t]{3}{*}{ RpsF } & 30 S ribosomal protein $S 6$ & Binds together with S18 to $16 \mathrm{~S}$ ribosomal RNA & 6.44 & $15163 / 5.26$ & 59 & 390 \\
\hline & DOWN-REGULATED & & & & & \\
\hline & Protein metabolism & & & & & \\
\hline FusA & Elongation factor $\mathrm{G}$ & $\begin{array}{l}\text { Catalyzes the GTP-dependent ribosomal translocation } \\
\text { step during translation elongation }\end{array}$ & 2.48 & $77722 / 5.17$ & 54 & 4521 \\
\hline PheT & $\begin{array}{l}\text { Phenylalanine-tRNA ligase } \\
\text { beta subunit }\end{array}$ & $\begin{array}{l}\text { ATP binding, magnesium ion binding, phenylalanine- } \\
\text { tRNA ligase activity, tRNA binding }\end{array}$ & Absent & $87968 / 5.13$ & 2 & 30 \\
\hline Pros & Proline-tRNA ligase & $\begin{array}{l}\text { Catalyzes the attachment of proline to tRNA(Pro) in a } \\
\text { two-step reaction: proline is first activated by ATP to } \\
\text { form Pro-AMP and then transferred to the acceptor end } \\
\text { of tRNA(Pro) }\end{array}$ & Absent & $63557 / 5.18$ & 53 & 1722 \\
\hline Def & Peptide deformylase & $\begin{array}{l}\text { Removes the formyl group from the N-terminal Met of } \\
\text { newly synthesized proteins }\end{array}$ & Absent & $19384 / 5.02$ & 27 & 194 \\
\hline GreA & $\begin{array}{l}\text { Transcription elongation } \\
\text { factor GreA }\end{array}$ & $\begin{array}{l}\text { Necessary for efficient RNA polymerase transcription } \\
\text { elongation past template-encoded arresting sites }\end{array}$ & Absent & $17702 / 4.75$ & 87 & 876 \\
\hline DsbA & $\begin{array}{l}\text { Thiol:disulfide interchange } \\
\text { protein DsbA }\end{array}$ & $\begin{array}{l}\text { Required for disulfide bond formation in some } \\
\text { periplasmic proteins such as PhoA or OmpA }\end{array}$ & Absent & $23011 / 5.65$ & 12 & 51 \\
\hline \multirow[t]{2}{*}{ SelD } & Selenide, water dikinase & Synthesizes selenophosphate from selenide and ATP & Absent & $36902 / 5.15$ & 23 & 656 \\
\hline & Carbon metabolism & & & & & \\
\hline Eno & Enolase & $\begin{array}{l}\text { Catalyzes the reversible conversion of } \\
\text { 2-phosphoglycerate into phosphoenolpyruvate }\end{array}$ & 2.20 & $45627 / 5.25$ & 61 & 2674 \\
\hline TpiA & $\begin{array}{l}\text { Triosephosphate } \\
\text { isomerase }\end{array}$ & Involved in the gluconeogenesis & 9.46 & $27071 / 5.68$ & 87 & 3640 \\
\hline Ppa & Inorganic pyrophosphatase & $\begin{array}{l}\text { Catalyzes the hydrolysis of inorganic pyrophosphate } \\
\text { (PPi) forming two phosphate ions. }\end{array}$ & 5.48 & $19778 / 5.01$ & 34 & 504 \\
\hline AcnA & Aconitate hydratase A & $\begin{array}{l}\text { Involved in the catabolism of short chain fatty } \\
\text { acids (SCFA) via the tricarboxylic acid (TCA)(acetyl } \\
\text { degradation route) and the 2-methylcitrate cycle I } \\
\text { (propionate degradation route) }\end{array}$ & Absent & $97840 / 5.30$ & 3 & 67 \\
\hline RhmA & $\begin{array}{l}\text { 2-keto-3-deoxy-L- } \\
\text { rhamnonate aldolase }\end{array}$ & $\begin{array}{l}\text { Catalyzes the reversible retro-aldol cleavage of } \\
\text { 2-keto-3-deoxy-L-rhamnonate (KDR) to pyruvate and } \\
\text { lactaldehyde }\end{array}$ & Absent & $28880 / 5.27$ & 5 & 43 \\
\hline Acs & $\begin{array}{l}\text { Acetyl-coenzyme A } \\
\text { synthetase }\end{array}$ & $\begin{array}{l}\text { Catalyzes the conversion of acetate into acetyl-CoA } \\
\text { (AcCoA), an essential intermediate at the junction of } \\
\text { anabolic and catabolic pathways }\end{array}$ & Absent & $72563 / 5.56$ & 12 & 160 \\
\hline PckA & $\begin{array}{l}\text { Phosphoenolpyruvate } \\
\text { carboxykinase [ATP] }\end{array}$ & Involved in the gluconeogenesis & Absent & $59895 / 5.67$ & 64 & 2721 \\
\hline GlpK & Glycerol kinase & $\begin{array}{l}\text { Catalyzes the phosphorylation of glycerol to yield sn- } \\
\text { glycerol 3-phosphate }\end{array}$ & Absent & $56301 / 5.42$ & 24 & 653 \\
\hline PykF & Pyruvate kinase I & $\begin{array}{l}\text { This protein is involved in step } 5 \text { of the subpathway } \\
\text { that synthesizes pyruvate from D-glyceraldehyde } \\
\text { 3-phosphate }\end{array}$ & Absent & 509675.66 & 23 & 428 \\
\hline $\operatorname{SdhA}$ & $\begin{array}{l}\text { Succinate dehydrogenase } \\
\text { flavoprotein subunit }\end{array}$ & $\begin{array}{l}\text { Two distinct, membrane-bound, FAD-containing } \\
\text { enzymes are responsible for the catalysis of fumarate } \\
\text { and succinate interconversion }\end{array}$ & Absent & $65048 / 5.91$ & 3 & 82 \\
\hline NuoE & $\begin{array}{l}\text { NADH-quinone } \\
\text { oxidoreductase subunit E }\end{array}$ & $\begin{array}{l}\mathrm{NDH}-1 \text { shuttles electrons from NADH, via FMN and } \\
\text { iron-sulfur (Fe-S) centers, to quinones in the respiratory } \\
\text { chain. The immediate electron acceptor for the enzyme } \\
\text { in this species is believed to be ubiquinone }\end{array}$ & Absent & $18875 / 5.29$ & 12 & 103 \\
\hline $\begin{array}{l}\text { STM } \\
1119\end{array}$ & $\begin{array}{l}\mathrm{NAD}(\mathrm{P}) \mathrm{H} \text { dehydrogenase } \\
\text { (quinone) }\end{array}$ & $\begin{array}{l}\text { Is na enzyme that catalyse the chemical reaction: } \\
\mathrm{NAD}(\mathrm{P}) \mathrm{H}+\mathrm{a} \text { quinone }=\mathrm{NAD}(\mathrm{P})++\mathrm{a} \text { hydroquinone }\end{array}$ & Absent & $20854 / 5.78$ & 27 & 77 \\
\hline GapA & $\begin{array}{l}\text { Glyceraldehyde-3- } \\
\text { phosphate dehydrogenase }\end{array}$ & $\begin{array}{l}\text { Catalyzes the oxidative phosphorylation } \\
\text { of glyceraldehyde 3-phosphate (G3P) to } \\
\text { 1,3-bisphosphoglycerate (BPG) using the cofactor NAD }\end{array}$ & Absent & $35735 / 6.33$ & 48 & 2607 \\
\hline
\end{tabular}


Table 1. (Continued)

\begin{tabular}{|c|c|c|c|c|c|c|}
\hline Protein & Protein name & $\begin{array}{l}\text { Protein function } \\
\text { (www.uniprot.org) }\end{array}$ & $\begin{array}{l}\text { Fold } \\
\text { change }\end{array}$ & $\begin{array}{l}\text { Nominal } \\
\text { mass/pI }\end{array}$ & $\begin{array}{l}\text { Sequence } \\
\text { coverage } \%\end{array}$ & $\begin{array}{c}\text { Mascot } \\
\text { score }\end{array}$ \\
\hline & Transmembrane transport & & & & & \\
\hline MalE & $\begin{array}{l}\text { Maltose-binding } \\
\text { periplamic protein }\end{array}$ & $\begin{array}{l}\text { Involved in the high-affinity maltose membrane } \\
\text { transport system }\end{array}$ & 7.60 & $43153 / 6.27$ & 18 & 435 \\
\hline FruB & $\begin{array}{l}\text { Multiphosphoryl transfer } \\
\text { protein }\end{array}$ & $\begin{array}{l}\text { This system is involved in fructose transport (By } \\
\text { similarity) }\end{array}$ & Absent & $39569 / 4.87$ & 68 & 4570 \\
\hline \multirow[t]{2}{*}{ HisJ } & $\begin{array}{l}\text { Histidine-binding } \\
\text { periplasmic protein }\end{array}$ & $\begin{array}{l}\text { Part of the histidine permease } A B C \text { transporter. Binds } \\
\text { histidine }\end{array}$ & Absent & $28476 / 6.03$ & 61 & 1387 \\
\hline & Nitrogen metabolism & & & & & \\
\hline GshB & Glutathione synthetase & $\begin{array}{l}\text { This protein is involved in step } 2 \text { of the subpathway } \\
\text { that synthesizes glutathione from L-cysteine and } \\
\text { L-glutamate }\end{array}$ & 5.56 & $35638 / 5.07$ & 29 & 441 \\
\hline DnaK & Chaperone protein Dnak & Acts as a chaperone & Absent & $69246 / 4.83$ & 50 & 3567 \\
\hline $\mathrm{HscB}$ & $\begin{array}{l}\text { Co-chaperone protein } \\
\text { HscB }\end{array}$ & $\begin{array}{l}\text { Co-chaperone involved in the maturation of iron-sulfur } \\
\text { cluster-containing proteins }\end{array}$ & Absent & 19996/5.08 & 6 & 45 \\
\hline GroL & $60 \mathrm{kDa}$ chaperonin & $\begin{array}{l}\text { Prevents misfolding and promotes the refolding and } \\
\text { proper assembly of unfolded polypeptides generated } \\
\text { under stress conditions }\end{array}$ & Absent & $57421 / 4.85$ & 57 & 4996 \\
\hline \multirow[t]{2}{*}{ RplE } & 50 S ribosomal protein L5 & $\begin{array}{l}\text { This is } 1 \text { of the proteins that binds and probably } \\
\text { mediates the attachment of the } 5 S \text { RNA into the large } \\
\text { ribosomal subunit, where it forms part of the central } \\
\text { protuberance }\end{array}$ & Absent & $20362 / 4.74$ & 20 & 26 \\
\hline & Nucleotides metabolism & & & & & \\
\hline Adk & Adenylate kinase & $\begin{array}{l}\text { Catalyzes the reversible transfer of the terminal } \\
\text { phosphate group between ATP and AMP }\end{array}$ & 8.56 & $23530 / 5.53$ & 49 & 1189 \\
\hline DeoA & Thymidine phosphorylase & $\begin{array}{l}\text { The enzymes which catalyze the reversible } \\
\text { phosphorolysis of pyrimidine nucleosides are involved } \\
\text { in the degradation of these compounds and in their } \\
\text { utilization as carbon and energy sources, or in the } \\
\text { rescue of pyrimidine bases for nucleotide synthesis }\end{array}$ & Absent & $47086 / 4.96$ & 41 & 860 \\
\hline Upp & $\begin{array}{l}\text { Uracil } \\
\text { phosphoribosyltransferase }\end{array}$ & $\begin{array}{l}\text { Catalyzes the conversion of uracil and 5-phospho- } \\
\text { alpha-D-ribose 1-diphosphate (PRPP) to UMP and } \\
\text { diphosphate }\end{array}$ & Absent & $22576 / 5.33$ & 7 & 42 \\
\hline DeoD & $\begin{array}{l}\text { Purine nucleoside } \\
\text { phosphorylase DeoD type }\end{array}$ & $\begin{array}{l}\text { Cleavage of guanosine or inosine to respective bases and } \\
\text { sugar-1-phosphate molecules }\end{array}$ & Absent & $26190 / 5.42$ & 9 & 22 \\
\hline \multirow[t]{2}{*}{ RpoA } & $\begin{array}{l}\text { DNA-directed RNA } \\
\text { polymerase subunit alpha }\end{array}$ & $\begin{array}{l}\text { DNA-dependent RNA polymerase catalyzes the } \\
\text { transcription of DNA into RNA using the four } \\
\text { ribonucleoside triphosphates as substrates }\end{array}$ & Absent & 36717 & 66 & 2351 \\
\hline & Oxidative stress & & & & & \\
\hline SodA & $\begin{array}{l}\text { Superoxide dismutase } \\
{[\mathrm{Mn}]}\end{array}$ & $\begin{array}{l}\text { Destroys superoxide anion radicals which are normally } \\
\text { produced within the cells and which are toxic to } \\
\text { biological systems }\end{array}$ & Absent & $23093 / 6.23$ & 5 & 66 \\
\hline SodB & Superoxide dismutase $[\mathrm{Fe}]$ & $\begin{array}{l}\text { Destroys superoxide anion radicals which are normally } \\
\text { produced within the cells and which are toxic to } \\
\text { biological systems }\end{array}$ & Absent & $16000 / 6.12$ & 52 & 2171 \\
\hline \multirow[t]{2}{*}{ SodC } & $\begin{array}{l}\text { Superoxide dismutase } \\
{[\mathrm{Cu}-\mathrm{Zn}] 2}\end{array}$ & $\begin{array}{l}\text { Destroys radicals which are normally produced within } \\
\text { the cells and which are toxic to biological systems }\end{array}$ & Absent & $17897 / 6.03$ & 16 & 65 \\
\hline & Amino acid metabolism & & & & & \\
\hline ArgI & $\begin{array}{l}\text { Ornithine } \\
\text { carbamoyltransferase }\end{array}$ & $\begin{array}{l}\text { Reversibly catalyzes the transfer of the carbamoyl group } \\
\text { from carbamoyl phosphate }(\mathrm{CP}) \text { to the } \mathrm{N} \text { (epsilon) atom } \\
\text { of ornithine (ORN) to produce L-citrulline }\end{array}$ & Absent & $36917 / 5.39$ & 17 & 453 \\
\hline \multirow[t]{2}{*}{ DksA } & $\begin{array}{l}\text { RNA polymerase-binding } \\
\text { transcription factor DksA }\end{array}$ & $\begin{array}{l}\text { Required for negative regulation of rRNA expression } \\
\text { and positive regulation of several amino acid } \\
\text { biosynthesis promoters }\end{array}$ & Absent & $17733 / 5.06$ & 29 & 778 \\
\hline & Quorum sensing & & & & & \\
\hline LuxS & $\begin{array}{l}\text { S-ribosylhomocysteine } \\
\text { lyase }\end{array}$ & $\begin{array}{l}\text { Involved in the synthesis of autoinducer } 2 \text { (AI-2) which } \\
\text { is secreted by bacteria and is used to communicate } \\
\text { both the cell density and the metabolic potential of the } \\
\text { environment }\end{array}$ & Absent & 19467/5.71 & 15 & 73 \\
\hline
\end{tabular}




\section{Search Tool for Retrieval of Interacting Genes/Proteins analysis (STRING)}

Analysis of identified proteins was performed using protein interaction information from the STRING database and visualized using Cytoscape (Fig. 1). STRING analyses revealed that up-regulated proteins involved in carbon and protein me- tabolism, transmembrane transport and nitrogen metabolism showed interaction with down-regulated proteins of the same categories. Proteins involved with oxidative stress and nucleotides metabolism showed no interaction with others. These results suggest that carvacrol could promote a multisite disturbance in $S$. Typhimurium biofilm.

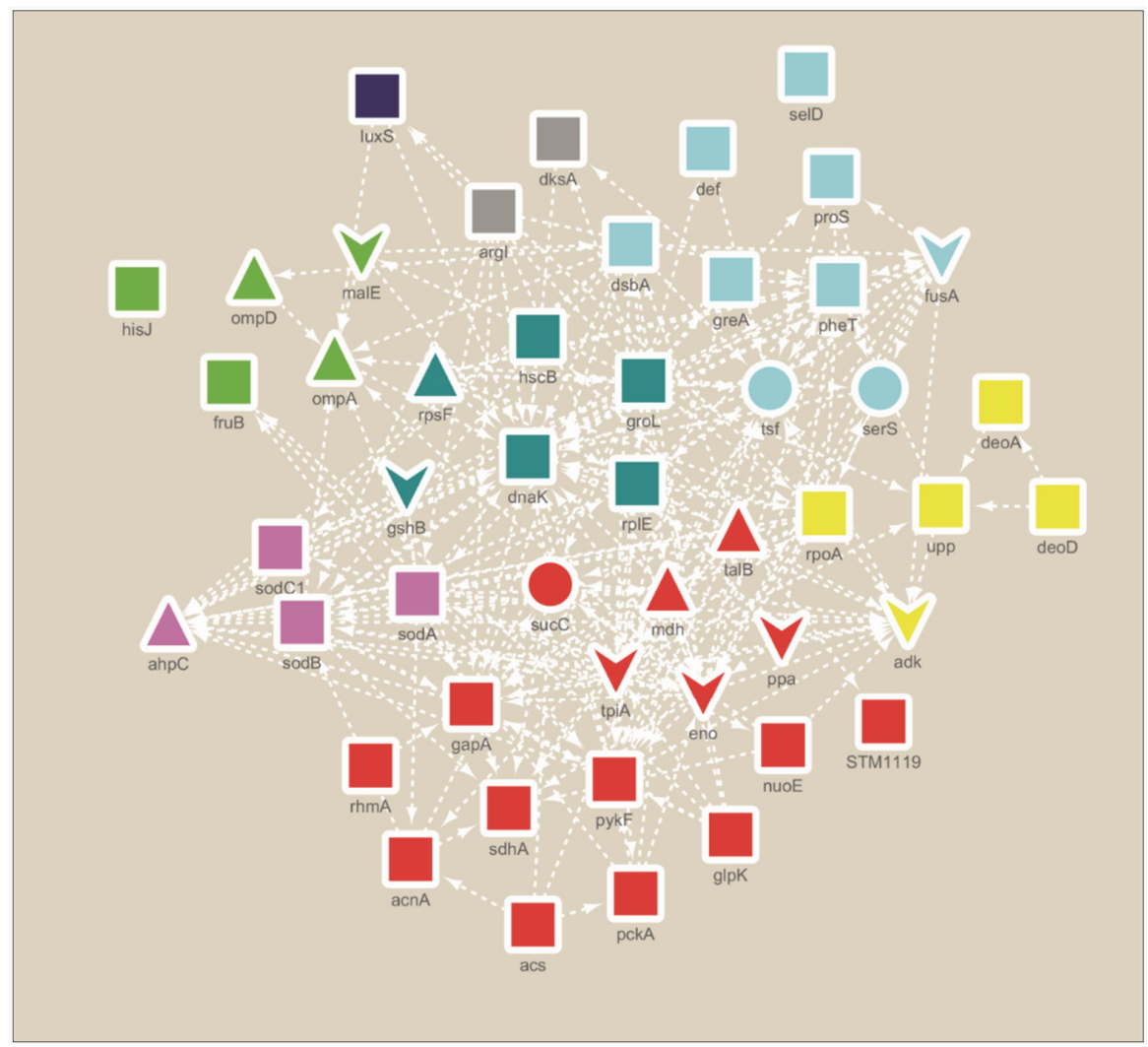

Fig. 1. A network of functional interactions between proteins altered in $S$. Typhimurium biofilm treatment with carvacrol. The nodes represent the proteins, and the edges represent the predicted functional associations. The proteins expressed only after treatment represented as circle; proteins that were observed only in the control gel was represented as square; proteins up-regulated after treatment represented as triangle and down-regulated proteins as represented as inverted triangle. Nodes are colored in red represent the proteins of the carbon metabolism; in aqua the protein metabolism; in teal the nitrogen metabolism; in lawn green the transmembrane transport; in yellow the metabolism of nucleotides; in magenta the oxidative stress; in gray the amino acid metabolism and in dark blue the quorum sensing.

\section{Discussion}

Recently, the effectiveness of carvacrol against bacterial biofilms has been investigated including those formed by Salmonella spp. (Amaral et al., 2015; Burt et al., 2014; Soni et al., 2013; Trevisan et al., 2018). Nevertheless, the mechanism of action of carvacrol against biofilms has not been completely elucidated. Burt et al. (2014) suggested that the mechanism by which carvacrol inhibits biofilm formation may be linked to the disruption of quorum sensing. Nostro et al. (2009), hypothesized that carvacrol, due to their amphipathic nature, could diffuse through the polysaccharide matrix of the biofilm and destabilize it. According to our knowledge, this is the first study reporting the changes in the protein profile of $S$. Typhimurium biofilm exposed to carvacrol, formed on a polypropylene surface.

Several changes in protein profile of biofilm cells were observed after treatment with carvacrol and main protein functions were showed in Table 1 . Proteins that show differentially expression were searched in Uniprot and in scientific literature aiming to know their function. We decided to discuss only proteins that were directly related to bacterial biofilms.

DsbA (thiol: disulfide interchange protein DsbA; protein metabolism) was decreased after treatment. This protein is part of the DSB (DiSulfide Bond) system that was first characterized in Escherichia coli K-12 (Jarrott et al., 2010). Proteins of this system are essential for the oxidative folding of secreted proteins in Gram-negative bacteria (Heras et al., 2010).

The DsbA protein inserts a reversible covalent disulfide bond in proteins exported from the cytoplasm to the periplasm. The disulfide bond formation adds stability to the proteins, allowing them to resist hostile extracellular environments (Shouldice et al., 2011). The oxidative folding system of DsbA and DsbB proteins has an important role in bacterial virulence. For instance, DsbA catalyzes the correct folding of proteins involved in bacterial pathogenicity such as proteins associated with adhesion, toxin production, and cellular spread (Heras et al., 2009). The role of DsbA has also been related to the virulence and biofilm formation of others pathogens including Salmonella spp. (Anwar et al., 2014; Lee et al., 2008; 2011). 
Anwar et al. (2014) studied the contribution of DsbA to the biofilm formation of S. Typhimurium using DsbA- or DsbB-deficient strains and observed that the mutant strains exhibited a loss of biofilm formation, showing that DsbA is important in biofilm formation. In our study, the synthesis of the DsbA protein was decreased after treatment with $624 \mu \mathrm{g} / \mathrm{ml}$ of carvacrol, suggesting that the antibiofilm property of this compound may be associated with the reduction of the relative quantity of this protein. Interestingly, Mangalappalli-Illathu and Korber (2006) observed that DsbA was up-regulated in the biofilm of Salmonella Enteritidis after adaptation with benzalkonium chloride. However, this study aimed to understand the mechanisms of development of adaptive resistance in $S$. Enteritidis biofilms after sublethal exposure to benzalkonium chloride.

Another protein that was also decreased after treatment of $S$. Typhimurium biofilm with carvacrol was S-ribosylhomocysteine lyase (LuxS; quorum sensing). This protein is involved in quorum sensing, a process of intercellular communication important to bacterial virulence and biofilm formation (Borges et al., 2016; Jiang and $\mathrm{Li}, 2013$ ). This process occurs by releasing, sensing, and responding to small diffusible signal molecules termed autoinducers (Borges et al., 2016; Jiang and Li, 2013; Li and Tian, 2012). S. Typhimurium produces and releases autoinducer-2 (AI-2) as a signaling molecule and the luxS gene is required for its synthesis (Surette et al., 1999).

It has been shown that the luxS gene is necessary for virulence and biofilm formation in $S$. Typhimurium (Choi et al., 2007; Jesudhasan et al., 2010). Jesudhasan et al. (2010) studied the effects of deletion of luxS on the formation of S. Typhimurium biofilm and observed that mutant strains formed significantly less biofilm than the wild strain, indicating that luxS is involved in the biofilm formation process.

Burt et al. (2014), using other approaches, reported that carvacrol inhibited $S$. Typhimurium biofilm formation, probably by disrupting quorum sensing signaling. Similar to findings by Burt et al. (2014), our previous study also showed the ability of carvacrol to decrease $S$. Typhimurium biofilm (Trevisan et al., 2018), corroborating with the hypothesis that these results may be a consequence of reduction of relative quantity of luxS.

Carvacrol also decreased relative quantity of DksA (RNA polymerase binding transcription factor DksA; amino acid metabolism) which was previously related to biofilm formation and pathogenicity of $S$. Typhimurium (Azriel et al., 2016). The latter authors characterized the role of DksA in S. Typhimurium biofilm using a $S$. Typhimurium $d k s A$ mutant strain and observed that the ability of these bacteria to form biofilms was significantly decreased in the absence of $d k s A$. In our study, after treatment with carvacrol, the DksA was decreased, suggesting that the antibiofilm property of this compound may also be associated with the reduction in relative quantity of this protein.

Proteins involved in the generation of reducing agents were also affected by carvacrol treatment. The increased in the relative quantity of protein transaldolase B (TalB; carbon metabolism) involved in the pentose shunt process deviates the substrate from one of the main mechanisms of generation of antioxidant agents, the pentose phosphate pathway. The diminished quantity of proteins $\mathrm{NAD}(\mathrm{P}) \mathrm{H}$ dehydrogenase (STM1119; carbon metabolism), superoxide dismutase [Mn] (SodA; oxidative stress), superoxide dismutase [Fe] (SodB; oxidative stress), superoxide dismutase [ $\mathrm{Cu}-\mathrm{Zn}]$ (SodC; oxidative stress), selenite water dikinase (SelD; protein metabolism), and glutathione synthetase (GshB; nitrogen metabolism), all involved in reduction reactions of oxidized components in the cell, supports the aforementioned hypothesis.

Carvacrol presents reducing activity as shown by the antioxidant assays. In this way, we hypothesize that the cell mechanism for production of reducing agents would not be so required. Therefore, this mechanism may have been suppressed due to carvacrol treatment. The fact that a reducing substance is high in the cell would certainly cause an imbalance of the oxidation-reduction reaction system, which is one of the mechanisms controlling the cellular process. This would justify why so many proteins from different mechanisms were found to be down regulated. In an effort to maintain cellular homeostasis, the protein alkyl hydroperoxide reductase subunit c (AhpC; oxidative stress) that is involved in maintenance of cell oxidation-reduction homeostasisis was present in high quantity (Parsonage et al., 2008). In addition, the antioxidant superoxide dismutase (SOD) protein as previously been found to be associated with bacterial virulence and biofilm formation (Kim et al., 2006; Krishnakumar et al., 2004; Suo et al., 2012). The SODs are metalloproteins that catalyze the toxic superoxide radicals to oxygen and hydrogen peroxide as protective reactions to remove cytotoxic free radicals from cells (McCord and Fridovich, 1969). Proteomic analyses performed by Kim et al. (2006) examined the role of SOD in the biofilm formation of Escherichia coli O157:H7. They showed that SodC had a significantly higher relative quantity in biofilms than under planktonic conditions. In the same study, it was observed that the deletion of sodC in E. coli O157:H7 reduced the attachment to abiotic surfaces during static growth. Trémoulet et al. (2002) compared differences between protein patterns of Listeria monocytogenes biofilm and planktonic cells and found that SOD protein was increased in the biofilm state. In another study, Suo et al. (2012) evaluated the role of SOD in L. monocytogenes formation. The authors observed that the mutant of sod presented reduced ability to form biofilm (Suo et al., 2012). These studies suggest that the sod gene plays a significant role in the development of biofilms. In our study, relative quantities of SodA, SodB, and SodC proteins were decreased after treatment with carvacrol. These results support the idea that this treatment affects the system of response to oxidative stress and that decreased synthesis of SOD can disestablish biofilm.

\section{Conclusions}

The proteomic analysis evidenced the action of carvacrol in proteins that can play a key role in $S$. Typhimurium biofilm formation. We highlight the decrease in the relative quantity of DsbA, LuxS, DksA and SODs proteins, important in bacterial biofilm, after treatment with carvacrol. Others tools beyond proteomics analysis can be applied to gain more insight into the mechanism of action of carvacrol on biofilm of S. Typhimurium.

\section{Conflict of interests}

The authors declare that they have no conflict of interests.

\section{Acknowledgements}

This study was financed in part by the Coordenação de Aperfeiçoamento de Pessoal de Nível Superior - Brasil (CAPES) Finance Code 001 and the Complexo de Centrais de Apoio à Pesquisa (COMCAP) of the State University of Maringá. We also thank the Laboratory of Mass Spectrometry at the Brazilian Biosciences National Laboratory (LNBio), CNPEM, Campi- 
nas, Brazil for their support with the use of RP-nano UPLC (nanoAcquity, Waters) equipment coupled with a Q-Tof Premier mass spectrometer (Waters).

\section{References}

Amaral VCS, Santos PR, Silva AF, Santos AR, Machinski M, Jr., Mikcha JMG (2015). Effect of carvacrol and thymol on Salmonella spp. biofilms on polypropylene. Int J Food Sci Technol 50: 2639-2643. DOI: 10.1111/ijfs.12934.

Anwar N, Rouf SF, Römling U, Rhen M (2014). Modulation of biofilm-formation in Salmonella enterica serovar Typhimurium by the periplasmic DsbA/DsbB oxidoreductase system requires the GGDEF-EAL domain protein STM3615. PLoS One 9(8): e106095. DOI: 10.1371/journal.pone.0106095.

Aragão AZB, Belloni M, Simabuco FM, Zanetti MR, Yokoo S, Domingues RR, et al. (2012). Novel processed form of syndecan-1 shed from SCC-9 cells plays a role in cell migration. PLoS One 7(8): e43521. DOI: 10.1371/journal.pone.0043521.

Azriel S, Goren A, Rahav G, Gal-Mor O (2016). The stringent response regulator DksA is required for Salmonella enterica Serovar Typhimurium growth in minimal medium, motility, biofilm formation, and intestinal colonization. Infect Immun 84(1): 375-384. DOI: 10.1128/IAI.01135-15.

Borges A, Abreu AC, Dias C, Saavedra MJ, Borges F, Simões M (2016). New perspectives on the use of phytochemicals as an emergent strategy to control bacterial infections including biofilms. Molecules 21(7): 877. DOI: 10.3390/molecules21070877.

Bradford M (1976). A rapid and sensitive method for the quantitation of microgram quantities of protein utilizing the principle of protein-dye binding. Anal Biochem 72: 248-254.

Bridier A, Sanchez-Vizuete P, Guilbaud M, Piard JC, Naitali M, Briandet R (2015). Biofilm-associated persistence of foodborne pathogens. Food Microbiol 45: 167-178. DOI: 10.1016/j. fm.2014.04.015.

Burt S (2004). Essential oils: their antibacterial properties and potential applications in foods - a review. Int J Food Microbiol 94(3): 223-253. DOI: 10.1016/j.ijfoodmicro.2004.03.022.

Burt SA, Ojo-Fakunle VTA, Woertman J, Veldhuizen EJA (2014) The natural antimicrobial carvacrol inhibits quorum sensing in Chromobacterium violaceum and reduces bacterial biofilm formation at sub-lethal concentrations. PLoS One 9(4): e93414. DOI: 10.1371/journal.pone.0093414.

Cappitelli F, Polo A, Villa F (2014). Biofilm formation in food processing environments is still poorly understood and controlled. Food Eng Rev 6(1-2): 29-42. DOI: 10.1007/s12393-014-9077-8.

Center for Disease Control and Prevention - CDC (2018). National Salmonella Surveillance. [online] [cit. 2019-03-05]. Available at: https://www.cdc.gov/nationalsurveillance/salmonellasurveillance.html

Center for Disease Control and Prevention - CDC (2019). [online] [cit. 2019-04-15]. Available at: https://www.cdc.gov/salmonella/ index.html

Choi J, Shin D, Ryu S (2007). Implication of quorum sensing in Salmonella enterica serovar Typhimurium virulence: The luxS gene is necessary for expression of genes in pathogenicity island 1. Infect Immun 75(10): 4885-4890. DOI: 10.1128/IAI.01942-06.

Cline MS, Smoot M, Cerami E, Kuchinsky A, Landys N, Wokman C, et al. (2007). Integration of biological networks and gene expression data using cytoscape. Nat Protoc 2(10): 2366-2382. DOI: $10.1038 /$ nprot.2007.324.

Condell O, Sheridan Á, Power KA, Bonilla-Santiago R, Sergeant K, Renaut J, et al. (2012). Comparative proteomic analysis of Salmonella tolerance to the biocide active agent triclosan. J Proteomics 75(14): 4505-45019. DOI: 10.1016/j. jprot.2012.04.044.

Erel O (2004). A novel automated direct measurement method for total antioxidant capacity using a new generation, more stable ABTS radical cation. Clin Biochem 37(4): 277-285. DOI: 10.1016/j.clinbiochem.2003.11.015.
FDA/Food and Drug Administration (2019). Food additives permitted for direct addition to food for human consumption. U.S. [online] [cit. 2020-07-28]. Available at: https://www.accessdata. fda.gov/scripts/cdrh/cfdocs/cfcfr/CFR Search.cfm?FR=172.515

Giaouris E, Samoilis G, Chorianopoulos N, Ercolini D, Nychas GJ (2013). Differential protein expression patterns between planktonic and biofilm cells of Salmonella enterica serovar Enteritidis PT4 on stainless steel surface. Int J Food Microbiol 162(1): 105-113. DOI: 10.1016/j.ijfoodmicro.2012.12.023.

Heras B, Shouldice SR, Totsika M, Scanlon MJ, Schembri MA, Martin JL (2009). DSB proteins and bacterial pathogenicity. Nat Rev Microbiol 7(3): 215-225. DOI: 10.1038/nrmicro2087.

Heras B, Totsika M, Jarrott R, Shouldice SR, Guntar G, Achard MES, et al. (2010). Structural and functional characterization of three DsbA paralogues from Salmonella enterica serovar Typhimurium. J Biol Chem 285(24): 18423-18432. DOI: 10.1074/jbc. M110.101360.

Jarrott R, Shouldice SR, Gunčar G, Totsika M, Schembri MA, Heras B (2010). Expression and crystallization of SeDsbA, SeDsbL and SeSrgA from Salmonella enterica serovar Typhimurium. Acta Cryst 66(5): 601-604. DOI: 10.1107/S1744309110011942.

Jensen LJ, Kuhn M, Stark M, Chaffron S, Creevey C, Muller J, et al. (2009). STRING 8 - A global view on proteins and their functional interactions in 630 organisms. Nucleic Acids Res 37 (Suppl. 1): 1-73. DOI: 10.1093/nar/gkn760.

Jesudhasan, PR, Cepeda, ML, Widmer, K, Dowd, SE, Soni KA, Hume ME, et al. (2010). Transcriptome analysis of genes controlled by luxS/autoinducer-2 in Salmonella enterica serovar Typhimurium. Foodborne Pathog Dis 7(4): 399-410. DOI: $10.1089=$ fpd.2009.0372.

Jiang T, Li M (2013). Quorum sensing inhibitors: a patent overview. Expert Opin Ther Patents 23(7): 867-894. DOI: 10.1517/13543776.2013.779674.

Kim YH, Lee Y, Kim S, Yeom J, Yeom S, Kim BS, et al. (2006). The role of periplasmic antioxidant enzymes (superoxide dismutase and thiol peroxidase) of the Shiga toxin-producing Escherichia coli O157:H7 in the formation of biofilms. Proteomics 6(23): 6181-6193. DOI: 10.1002/pmic.200600320.

Knowles JR, Roller S, Murray DB, Naidu AS (2005.) Antimicrobial action of carvacrol at different stages of dual-species biofilm development by Staphylococcus aureus and Salmonella enterica serovar Typhimurium. Appl Environ Microbiol 71(2): 797-803. DOI: 10.1128/AEM.71.2.797-803.2005.

Krishnakumar R, Craig M, Imlay JA, Slauch JM (2004). Differences in enzymatic properties allow SodCI but not SodCII to contribute to virulence in Salmonella enterica serovar Typhimurium strain 14028. J Bacteriol 186(16): 5230-5238. DOI: 10.1128/JB.0001007.

Lee Y, Kim Y, Yeom S, Kim S, Park S, Jeon CO, et al. (2008). The role of disulfide bond isomerase A (DsbA) of Escherichia coli O157:H7 in biofilm formation and virulence. FEMS Microbiol Lett 278(2): 213-222. DOI: 10.1111/j.1574-6968.2007.00993.x.

Lee Y, Seo H, Yeom J, Park W (2011). Molecular characterization of the extracellular matrix in a Pseudomonas putida dsbA mutant: Implications for acidic stress defense and plant growth. Res Microbiol 162(3): 302-310. DOI: 10.1016/j.resmic.2010.11.002.

Li YH, Tian X (2012). Quorum sensing and bacterial social interactions in biofilms. Sensors 12(3): 2519-2538. DOI: 10.3390/ s120302519.

Magalhães S, Aroso M, Roxo I, Ferreira S, Cerveira F, Ramalheira E, et al. (2017). Proteomic profile of susceptible and multidrugresistant clinical isolates of Escherichia coli and Klebsiella pneumoniae using label-free and immunoproteomic strategies. Res Microbiol 168(3): 222-233. DOI: 10.1016/j.resmic.2016.12.002.

Mangalappalli-Illathu AK, Korber DR (2006). Adaptive resistance and differential protein expression of Salmonella enterica serovar Enteritidis biofilms exposed to benzalkonium chloride. Antimicrob Agents Chemother 50(11): 3588-3596. DOI: 10.1128/AAC.0057306.

Mangalappalli-Illathu AK, Lawrence JR, Swerhone GDW, Korber DR (2008). Architectural adaptation and protein expression patterns of Salmonella enterica serovar Enteritidis biofilms under laminar flow conditions. Int J Food Microbiol 123(1-2): 109-120. DOI: 10.1016/j.ijfoodmicro.2007.12.021. 
McCord JM, Fridovich I (1969). Superoxide Dismutase An enzymic function for erythrocuprein (hemocuprein). J Biol Chem 244(25): 6049-1969.

Neuhoff V, Arold N, Taube D, Ehrhardt W (1988). Improved staining of proteins in polyacrylamide gels including isoelectric focusing gels with clear background at nanogram sensitivity using Coomassie Brilliant Blue G-250 and R-250. Electrophoresis 9(6): 255-262. DOI: 10.1002/elps.1150090603.

Nostro A, Marino A, Blanco AR, Cellini L, Giulio MD, Pizzimenti F et al. (2009). In vitro activity of carvacrol against staphylococcal preformed biofilm by liquid and vapour contact. J Med Microbiol 58(6): 791-797. DOI: 10.1099/jmm.0.009274-0.

Parsonage D, Karplus PA, Poole LB (2008). Substrate specificity and redox potential of AhpC, a bacterial peroxiredoxin. Proc Natl Acad Sci 105(24): 8209-8214. DOI: 10.1073_pnas.0708308105.

Sharma P, Kumar B, Gupta Y, Singhal N, Katoch VW, Venkatesan K, et al. (2010). Proteomic analysis of streptomycin resistant and sensitive clinical isolates of Mycobacterium tuberculosis. Proteome Sci 8(1): 59. DOI: 10.1186/1477-5956-8-59.

Shevchenko A, Wilm M, Vorm O, Mann M (1996). Mass spectrometric sequencing of proteins from silver-stained polyacrylamide gels. Anal Chem 68(5): $850-858$. DOI: 10.1021/ ac950914h.

Shouldice SR, Heras B, Walden PM, Totsika M, Schembri MA, Martin JL (2011). Structure and function of DsbA, a key bacterial oxidative folding catalyst. Antioxid Redox Signal 14(9): 17291760. DOI: $10.1089=$ ars. 2010.3344

Silva AF, Santos AR, Trevisan DAC, Ribeiro AB, Campanerut-Sá PAZ, Kukolj C, et al. (2018). Cinnamaldehyde induces changes in the protein profile of Salmonella Typhimurium biofilm. Res Microbiol 169(1): 33-43. DOI: 10.1016/j.resmic.2017.09.007.

Soares AA, Souza CGM, Daniel FM, Ferrari GP, Costa SMG, Peralta RM (2009). Antioxidant activity and total phenolic content of Agaricus brasiliensis (Agaricus blazei Murril) in two stages of maturity. Food Chem 112(4): 775-781. DOI: 10.1016/j. foodchem.2008.05.117.

Soni KA, Oladunjoye A, Nannapaneni R, Schilling MW, Silva JL, Mikel B, et al. (2013). Inhibition and inactivation of Salmonella Typhimurium biofilms from polystyrene and stainless steel surfaces by essential oils and phenolic constituent carvacrol. J Food Prot 76(2): 205-212. DOI: 10.4315/0362-028X.JFP12-196.

Steenackers H, Hermans K, Vanderleyden J, De Keersmaecker SCJ (2012). Salmonella biofilms: An overview on occurrence, structure, regulation and eradication. Food Res Int 45(2): 502-531. DOI: 10.1016/j.foodres.2011.01.038.

Suo Y, Huang Y, Liu Y, Shi C, Shi X (2012). The expression of superoxide dismutase (SOD) and a putative $A B C$ transporter permease is inversely correlated during biofilm formation in Listeria monocytogenes 4b G. PLoS One 7(10): e48467. DOI: 10.1371/journal.pone.0048467.

Surette MG, Miller MB, Bassler BL (1999). Quorum sensing in Escherichia coli, Salmonella typhimurium, and Vibrio harveyi: a new family of genes responsible for autoinducer production. Proc Natl Acad Sci U S A 96(4): 1639-1644. DOI: 10.1073/pnas.96.4.1639.

Tapia-Rodriguez MR, Hernandez-Mendoza A, Gonzalez-Aguilar GA, Martinez-Tellez MA, Martins CM, Ayala-Zavala F (2017). Carvacrol as potential quorum sensing inhibitor of Pseudomonas aeruginosa and biofilm production on stainless steel surfaces. Food Control 75: 255-261. DOI: 10.1016/j.foodcont.2016.12.014.

Tomlinson IM, Holt LJ (2001). Protein profiling comes of age. Genome Biol 2(2). DOI: 10.1186/gb-2001-2-2-reviews1004.

Trémoulet F, Duché O, Namane A, Martinie B (2002). Comparison of protein patterns of Listeria monocytogenes grown in biofilm or in planktonic mode by proteomic analysis. FEMS Microbiol Lett 210(1): 25-31. DOI: 10.1111/j.1574-6968.2002.tb11155.x.

Trevisan DAC, Silva AF, Negri M, Abreu Filho BA, Machinski Junior M, Patussi EV, et al. (2018). Antibacterial and antibiofilm activity of carvacrol against Salmonella enterica serotype Typhimurium. Brazilian J Pharm Sci. 54(1): e17229. DOI: 10.1590/s2175-97902018000117229.

Uchida NS, Grespan R, Piovezan M, Ferreira EC, Machinski Junior M, Cuman RKN, et al. (2014). Effect of carvacrol on Salmonella Saintpaul biofilms on stainless steel surface. Trop J Pharm Res 14: 1075-1079. DOI: 10.4314/tjpr.v14i6.20.

Wagon S (1999). Mathematica in action - Problem Solving Through Visualization and Computation. Springer. Nova York (NY).

Walsh DJ, Livinghouse T, Goeres DM, Mettler M, Stewart PS (2019). Antimicrobial Activity of Naturally Occurring Phenols and Derivatives against Biofilm and Planktonic Bacteria. Front Chem 7: 1-13. DOI: 10.3389/fchem.2019.00653.

Wang H, Wang H, Xing T, Wu N, Xu X, Zhoug G (2016). Removal of Salmonella biofilm formed under meat processing environment by surfactant in combination with bio-enzyme. LWT - Food Sci Technol 66: 298-304. DOI: 10.1016/j.lwt.2015.10.049.

World Health Organization - WHO (2018). Salmonella. [online] [cit. 2018-04-14]. Available at: https://www.who.int/foodsafety/ areas_work/foodborne-diseases/salmonella/en/ 